\title{
Applying the Fuzzy Analytic Hierarchy Process to Construct the Product Innovative Service System of Wedding Photography Apparel
}

\author{
Jui-Che Tu and Chi-Ling Hu \\ Graduate School of Design, Master \& Doctoral Program, National Yunlin University of Science and Technology, \\ Douliou, Yunlin 640, Taiwan
}

Correspondence should be addressed to Chi-Ling Hu; justine@stu.edu.tw

Received 14 June 2014; Accepted 13 August 2014

Academic Editor: Teen-Hang Meen

Copyright (C) 2015 J.-C. Tu and C.-L. Hu. This is an open access article distributed under the Creative Commons Attribution License, which permits unrestricted use, distribution, and reproduction in any medium, provided the original work is properly cited.

\begin{abstract}
This study aimed to investigate the indicators of the wedding photography apparel product system in order to construct the wedding photography apparel product system indicators and analyze the hieratical weights of the wedding photography apparel product system indicators. By using the Delphi method and the fuzzy analytic hierarchy process, this study constructed the questionnaire for wedding photography apparel product system indicator weights. This study used the mean and standard deviation to learn about the distribution of opinions of the experts and scholars. According to the findings of this study, for the fuzzy weight analysis results of the wedding photography apparel product system indicators, the most important indicators are the product-service indicators. Moreover, for the product-service indicators, the wedding apparel package service is the most important. For the information platform indicator, the wedding apparel style opinion platform is the most important. For the maintenance and recycling indicators, the wedding apparel second-hand auction/donation is the most important. For the sales market indicators, the wedding apparel store sales/rental is the most important. The main purpose of the indicators of the wedding photography apparel product system constructed in this study is to propose detailed items and connotations to provide a substantial reference and basis of business strategic indicators for the wedding photography enterprises.
\end{abstract}

\section{Introduction}

1.1. Research Background and Motives. Nowadays, most of studies focus on operation of bridal photography companies. According to literature review, the researchers realize that, in early times, bridal photography companies had package service of lease. It means that photography companies started including related upstream and downstream services as multiple operations. Lease of dress and overall modeling are important new items. Currently, expenditures of bridal photography are high. Thus, many young people try to be simple and save money. There is the rise of green wedding or selfservice wedding dress. In the market, there are various kinds of companies of wedding dress lease. Some discounts are cheaper than purchase or lease of one piece of dress. In fairs of sales, wedding dress companies introduce different discounts and dresses. Thus, this study tries to explore the aspect. In addition, in bridal photography industry, the subjects who are going to get married are the main customers. Those who are not married tend to be neglected. In order to construct multiple customer-oriented product-service systems, sources of new customers are extremely important. How to meet customers' needs, enhance quality of product service, and control customers' needs is the research motive on operation of bridal photography companies.

1.2. Research Purposes. According to narrative research background and motivation, the wedding market supply and demand of today's presentation is accompanied, complex, and varied, resulting in wedding photography industry development and management. The wedding market will be subject to a severe test if the wedding photography companies set product-service system platform in service projects, providing more convenient personal studios. The general public 


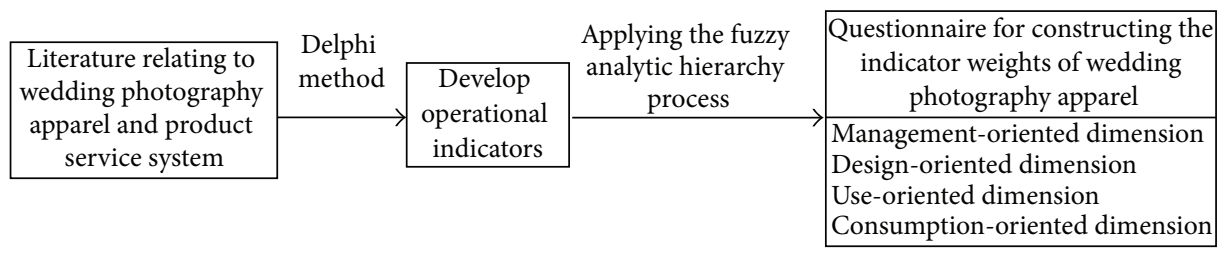

Figure 1: Research structure.

and related industries employ designers to create mutual operational effect, but the establishment of the existence of product-service system performance problems, the direction for the subsequent investigation. By investigating enterprises to explore the bride dress wedding photography company to construct a production system, the results of which aim to work out that it can bring real help to the wedding photography industry, and as a wedding photography company's innovative business services strategy reference.

\section{Literature Review}

(1) Current Situation and Development of Wedding Dress Industry in Taiwan. The bridal photography in Taiwan was launched in the 1970s. However, the development in different places of Taiwan was inconsistent. Generally speaking, it started from cities to countryside. In order to explain the process of the transformation, the said researcher divided it into three stages with corresponding times: beginning stage (1970s), transformation stage (1980s), and package service stage (1990s till present). Noticeably, in the same years, different places in Taiwan might experience different development stages. Thus, the classification by characteristics of development would be more precise. Characteristics of three stages are briefly introduced below. At beginning stage, photo studios started providing lease of wedding dress and became wedding service industry. At transformation stage, model of wedding dress stores was established. The new industry offered the services of wedding photography, wedding dress, and bridal modeling in the same studios [1].

(2) Product-Service Systems (PSS). Product-service systems are widely adopted. "Product-service systems" mean the products and services to satisfy consumers' needs. Such a model of meeting the "environmental protection" demand by "selling service" is in line with the concept of "PSS (productservice system)." "PSS" is based on environmental protection and economic considerations [2-5]. It combines product and service to satisfy the consumption demand in order to realize the purpose of dematerialization of the product $[6,7]$.

Three categories proposed by Tukker are the main indicators. "Product-oriented" and the business model to sell physical products. However, other services will be offered. As to "use-oriented," product-service systems are based on products. It aims to accomplish goals by using products. Users do not necessarily have the ownership of products. The ownership tends to belong to service providers. Products are usually used by different or multiple users. As to "resultoriented," when users are in need, service providers offer the result which directly satisfies users. The result might not be necessarily related to specific products. Based on three orientations, there are 8 categories [7].

\section{Materials and Methods}

3.1. Research Structure. This study first reviewed the literature relating to wedding photography apparel and product-service system to summarize the overall concept and developmental history. Then, Delphi method was applied to develop operational indicators. Based on the expert questionnaire survey results, this study designed the "questionnaire for constructing the indicator weights of wedding photography apparel." The questionnaire aims to compute management-oriented dimension, design-oriented dimension, use-oriented and consumption-oriented dimension weight values, and serially integrated weight by using FAHP (Figure 1).

3.2. Research Processes. Based on the above concepts, this study collected relevant literature to determine the theme and scope of the research. After literature review and discussion, the research purpose and questions were clarified: collect the relevant literature to form the research concepts, and determine the research theme. The discussed contents of the literature include (1) planning ideas and current situations of wedding photography companies; (2) wedding photography apparel product planning and current development situations; (3) review of the literature related to wedding photography apparel; (4) discussing wedding photography apparel product planning and constructing research literature analysis; and (5) illustration of Delphi method and FAHP procedure.

The research framework was constructed by collecting and reviewing the literature. The system indicators, dimensions, and question items of wedding photography apparel based on the literature analysis were sent to the 12 experts for discussion using the two-stage Delphi method. After retrieval of the questionnaires, views of experts and scholars were integrated to modify, add, or delete the questions. After calculation of consent rate, the wedding photography apparel product system indicators were confirmed. Based on this, the "questionnaire survey for wedding photography apparel system weight indicators" was developed.

Next, the 18 experts were invited to fill in the questionnaires to investigate the wedding photography apparel product system indicator weights. After questionnaires on indicator weights were recovered, FAHP was used to calculate and analyze the indicator weights. According to the relevant literature, the research results were discussed and summarized. At 


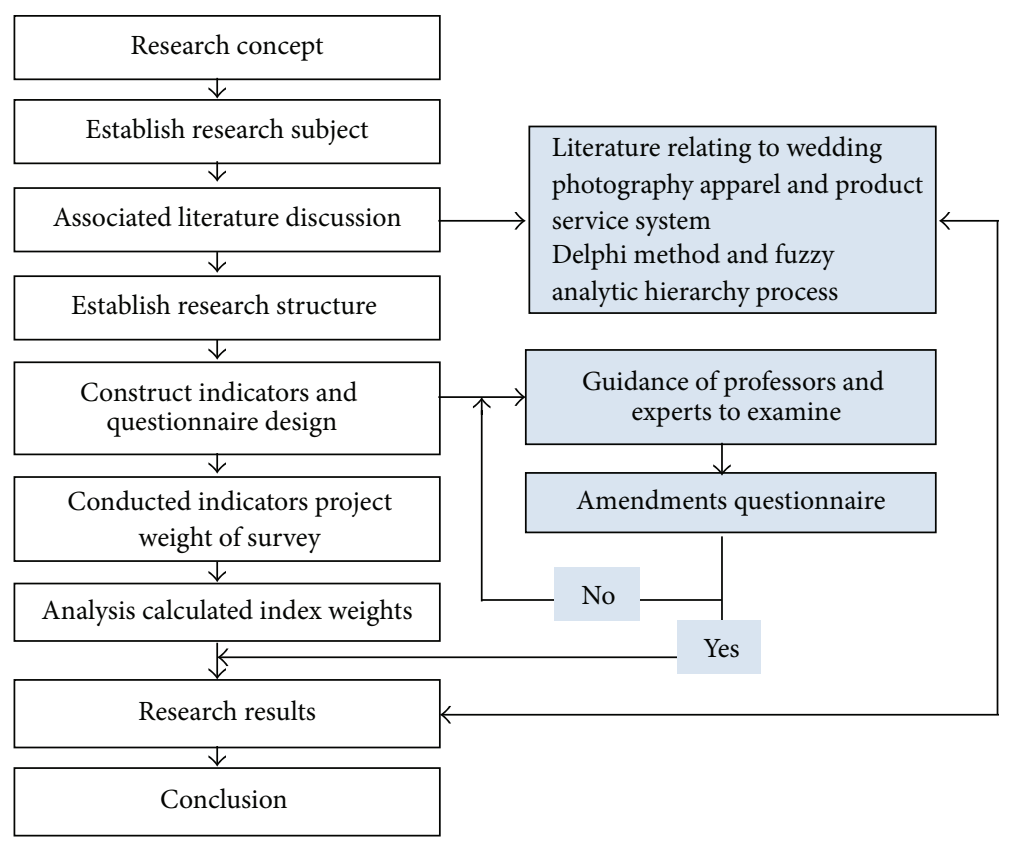

Figure 2: Research processes.

TABLE 1: Research subjects.

\begin{tabular}{|c|c|c|c|c|c|}
\hline & & Number & Industry/academia & People & Years \\
\hline \multirow{9}{*}{$\begin{array}{l}\text { Research subjects of the } \\
\text { relative weight analysis of the } \\
\text { indicators ( } 18 \text { experts) }\end{array}$} & \multirow{9}{*}{$\begin{array}{l}\text { Delphi method } \\
\text { experts (12 experts) }\end{array}$} & 1 & Gennysu wedding dress mall & 1 & 10 \\
\hline & & 2 & France \& Taipei & 1 & 11 \\
\hline & & 3 & Kaohsiung Fei Li Wedding Dress & 1 & 8 \\
\hline & & 4 & Fashionmonger Wedding & 1 & 9 \\
\hline & & 5 & Cang-ai Wedding & 1 & 10 \\
\hline & & 6 & Milan Wedding & 1 & 10 \\
\hline & & 7 & Ling Tung University, Department of Fashion Design & 2 & 8 \\
\hline & & 8 & Shu-Te University, Department of Fashion Design & 2 & 12 \\
\hline & & 9 & $\begin{array}{l}\text { Shih Chien University, Department of Fashion Design } \\
\text { and Merchandising }\end{array}$ & 2 & 6 \\
\hline & & 10 & Kaohsiung wedding dress (self-service wedding dress) & 2 & $10-12$ \\
\hline & & 11 & B.H WEDDING (self-service wedding dress) & 2 & 5 \\
\hline & & 12 & $\begin{array}{l}\text { MAC bridal photography studio (self-service wedding } \\
\text { dress) }\end{array}$ & 2 & 8 \\
\hline
\end{tabular}

Source: compiled by this study.

last, the research results and suggestions were proposed, and the research report was prepared to complete the research, as shown in Figure 2.

\subsection{Research Subjects}

(1) Delphi Method Experts. There is fixed model for the selection of Delphi method experts. In general, Delphi method requires 15-20 experts. In addition, there are two considerations: one is the number of experts needed to obtain representativeness; another is the researcher's ability to process information [8]. According to a study in Taiwan, the number of experts is highly flexible, possibly in the range from 10 to 15 . This study was conducted using Delphi method to collect the expert opinions. The questionnaire was named as "questionnaire for constructing the indicator weights of wedding photography apparel." The construction of indicators is based on chain wedding photography companies and private profit-making firms. Therefore, this study selected experts as representatives from both fields. A total of 12 experts were invited, and their professional fields met the requirements of this study. Hence, the results have considerable contributions to the establishment and assessment of system indicators (Table 1). 
(2) Research Subjects of the Relative Weight Analysis of the Indicators. After the retrieval of the two-stage Delphi expert questionnaires, this study developed the "questionnaire for constructing the indicator weights of wedding photography apparel products and services." The selection of the 18 experts was mainly based on the integration of theory and practice. Therefore, the questionnaire was considerably difficult to answer, requiring careful consideration of logic relationship. This study contacted experts and scholars for discussion before mailing the questionnaires to them, in order to increase the recovery rate (Table 1 ).

3.4. Research Tools. An effective measuring tool (questionnaires) includes three features: validity, reliability, and practicality. Validity means measuring tool can correctly measure idiosyncratic degree of the measured object; reliability means consistency or stability of the measured results; practicability concerns economical efficiency, convenience, and explanatory [9]. Thus, the complication and implementation of research tool should have validity and practicality.

(1) Questionnaires for Establishment of Wedding Photography Apparel Product System Indicators and Implementation. Delphi technique is a technical integrated research method and a group decision making method. The group members express their views on some issue anonymously in writing to reach consensus on the complicated issues. In addition, the Delphi technique was originally conceived as a way to obtain the opinion of experts without necessarily bringing them together face to face. Thus, the Delphi technique is also called expert judgment method. Based on expert knowledge and experience, a specific issue is answered repeatedly at least three times till the experts reached the consensus $[10,11]$.

(2) Compilation of Questionnaires for Wedding Photography Apparel System Indicator Weights and Implementation. This study constructed wedding photography apparel product indicator weight system. The confirmed measuring indicators in the 2-stage Delphi expert questionnaires were used to develop "questionnaires for indicators of wedding photography apparel product system indictor weights." The experts and scholars evaluated importance of indicators through pairwise comparison check. The evaluation has five scales: "absolutely important," "very important," "more important," "slightly important," and "equally important." There were 18 experts and scholars participating in the questionnaires.

\subsection{Data Processing}

(1) Descriptive Analysis. The data were analyzed for the mean and standard deviation of the indicators of the wedding photography apparel product system, in order to determine the importance of the indicators.

(2) Constructing the Wedding Photography Apparel Product System Using the Delphi Method. By literature review and the two-stage expert Delphi method modification, this study constructed the wedding photography apparel product system indicators. According to the research purposes and questionnaire scoring system, the systematic summary and computation reveal the opinion distribution of experts and scholars.

(3) Application of Software Expert Choice 2000. The "make model" function of the software Expert Choice 2000 was used to analyze the questionnaire results and construct the hierarchical structure system model for the wedding photography apparel product system indicators. Furthermore, based on the expert's selection and judgment value matrix, this study conducted the consistency analysis for each item using the subfunction of "importance" of the function of "compare." In addition, this study analyzed the overall expert selection and judgment value matrix and conducted the comparative analysis of hierarchical indicators to obtain the relative weights of various groups of indicators.

(4) Wedding Photography Apparel Product System Indicator Weight Analysis (FAHP). This study developed the weight questionnaire with indicators of the "wedding photography apparel product system indicator" and adopted FAHP to analyze the weight. The relative importance of the wedding photography apparel product system indicators, as well as the weights of various items or criteria, was obtained. Moreover, the consistency of the results was measured by C.I. value and C.R. value tests.

\section{Results and Discussion}

4.1. Discussion on the Questionnaire Results. According to the first stage expert Delphi method results, the consent rate of all question items has reached $90 \%$, suggesting that experts and scholars have reached a high degree of consensus. The average of some question items is lower than 4.0. However, these are the results of the first stage expert questionnaire. According to the second stage expert results, the consent rate of all question items has reached $90 \%$, suggesting that experts and scholars have reached a degree of consensus in the system indicator dimensions, indicators, and question items. In addition, the questionnaire items are in the stable distribution state, indicating that all experts have reached consensus in the second stage. Therefore, the expert questionnaire survey can be stopped [12].

This study summarized the first and the second expert questionnaire results for comparison. Except for some questionnaire items with greater average values in the second questionnaire results, the results of most questionnaire items were consistent in both questionnaires as shown in Table 2.

4.2. Analysis of the Indicator Fuzzy Weights. By using FAHP weight analysis, this study surveyed 18 experts and scholars. The weight questionnaires were sent on August 10, 2013, and retrieved on August 18. A total of 15 questionnaires were recovered and the return rate was $83 \%$. During the process of constructing the weight system for the indicators, the AHP hierarchical concepts and eigenvectors were applied in computation to acquire the consensus of experts and scholars 


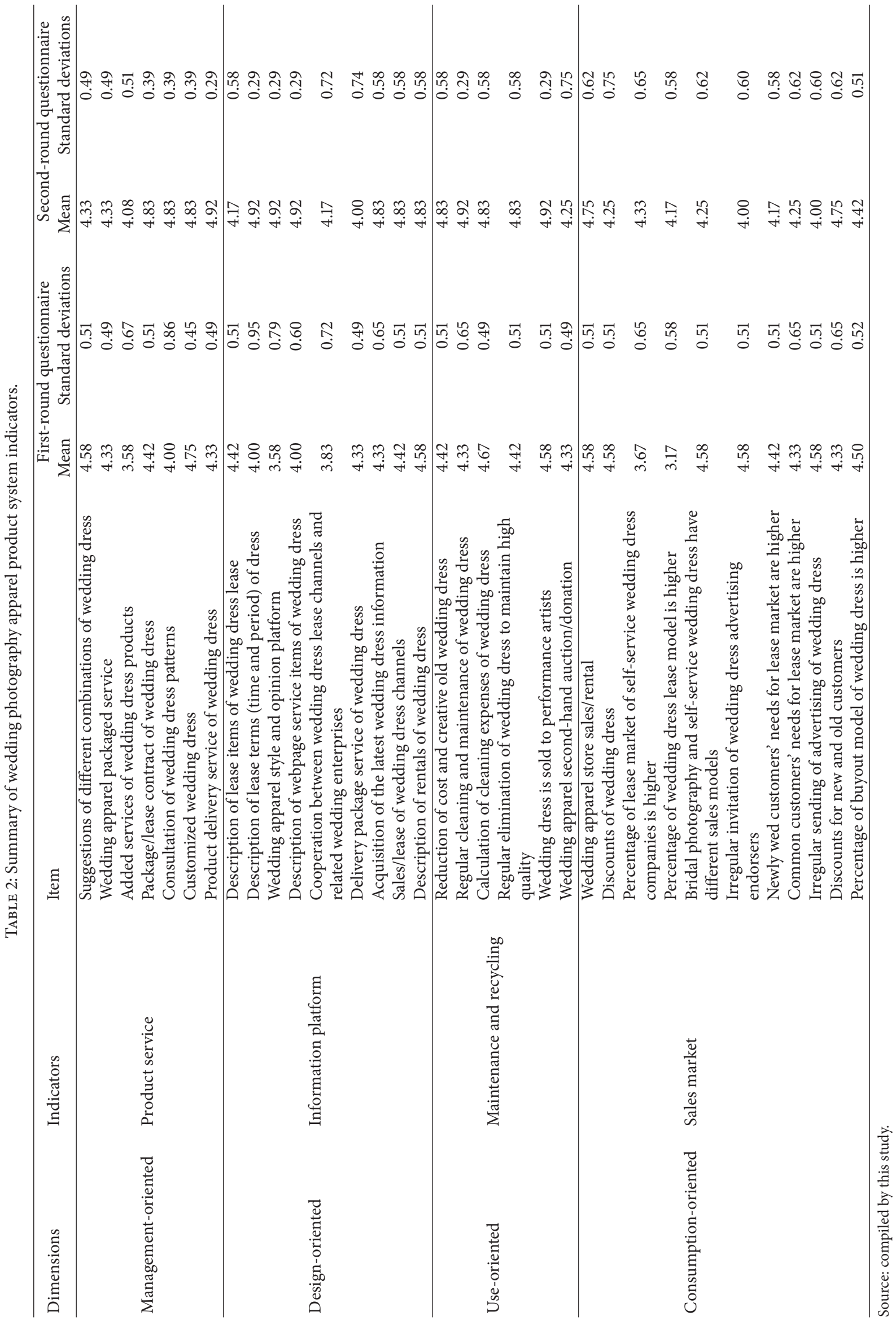


TABLE 3: R.I. reference table.

\begin{tabular}{lcccccccccc}
\hline Hierarchy & 1 & 2 & 3 & 4 & 5 & 6 & 7 & 8 & 9 & 10 \\
\hline R.I. & 0.00 & 0.00 & 0.58 & 0.90 & 1.12 & 1.24 & 1.32 & 1.41 & 1.45 & 1.49 \\
\hline
\end{tabular}

Source: compiled by this study.

TABLE 4: C.I. and C.R. values of indicator pairwise comparison matrix.

\begin{tabular}{lccc}
\hline Dimension & Indicator & Item & Value \\
\hline & Overall & C.I. & 0.00 \\
& & C.R & 0.000 \\
\hline \multirow{2}{*}{ Management-oriented } & \multirow{2}{*}{ Product service } & C.I. & 0.02 \\
& & C.R & 0.034 \\
\hline \multirow{2}{*}{ Design-oriented } & \multirow{2}{*}{ Information platform } & C.I. & 0.00 \\
& & C.R & 0.000 \\
\hline \multirow{2}{*}{ Use-oriented } & \multirow{2}{*}{ Maintenance and recycling } & C.I. & 0.02 \\
& & C.R & 0.034 \\
\hline \multirow{2}{*}{ Consumption-oriented } & \multirow{2}{*}{ Sales market } & C.I. & C.R \\
\hline
\end{tabular}

Source: compiled by this study.

on the system indicators and weights. Next, the analysis and sequence of the dimensions, indicators, and question items were carried out. Finally, by using FAHP proposed by Buckley [13], this study obtained the comprehensive judgment values of various indicators based on the evaluation criteria and used the triangular fuzzy number, fuzzy sequence, and hierarchical serial connection to obtain the weights of various key success factors, in order to learn about the sequence of wedding photography apparel product system indicator weights.

(1) Construct the Hierarchical Analysis Weights of the Indicators. In the hierarchical structure of system indicators, regarding the pairwise comparison matrix compromising the answers of the experts, Expert Choice 2000 was used for consistency test, and the consistency matrix of consistency index (C.I.) and consistency ratio (C.R.) was developed to determine whether the expert opinions are transitive. The evaluation criteria are referred to by Saaty [14]. The evaluation scale is the positive reciprocal matrix comprising 1-9. The generation of different C.I. values in the event of different number of hierarchies is known as the random index (R.I.). The ratio of C.I. value and R.I. value is known as the consistency ratio (C.R.), namely, C.R. = C.I./R.I.

Therefore, when C.R. value is lower than 0.1, the degree of consistency of the matrix is very high. R.I. reference values are as shown in Table 3.

4.3. Indicator Consistency Test. According to the analysis results as shown in Table 4, in the questionnaire result consistency test, C.I. and C.R. values of all the experts and scholars regarding the indicators are below 0.1, suggesting that the degree of various matrices is very high. In other words, the decision making process of the experts and scholars is reasonable and their viewpoints about factors of consideration are consistent. Therefore, the research findings can fully express the opinions of the respondents. In this study, the overall consistency of "product service" indicators is $0.034<0.1$, the overall consistency of the "information platform" indicators is $0.000<0.1$, the overall consistency of the "maintenance and recycling" is $0.034<0.1$, and the overall consistency of the "sales market" indicators is 0.017 $<0.1$, suggesting that the evaluation of the structure of the wedding photography apparel product system indicators is consistent.

Based on the expert consistency test of the system indicators, 15 experts and scholars have a high degree of consensus on the questionnaire. This suggests that the structural evaluation of the four wedding photography apparel product system indicators is consistent.

4.4. Indicator Weight. The indicator weight questionnaires were distributed to 12 experts and scholars. Expert Choice 2000 was applied in the analysis of the wedding photography apparel product system indicator weights, finding that the weight of the indicator of "product service" is the highest at .320 , followed by "information platform" indicator at .290, "maintenance and recycling" indicator at .150, and "sales market" indicator at .240 .

Regarding the weight of the hierarchies, among the "product service" indicators, the weight of the question item of "wedding apparel packaged service" weight is the highest at .222, accounting for the total hierarchical weight at .062 . Among the "information platform" indicators, the weight of the question item of "wedding apparel style and opinion platform" is the highest at .554, accounting for .053 of the total weight. Among "maintenance and reuse" indicators, the weight of "wedding apparel second-hand auction/donation" is the highest at .132, accounting for .037 of the total weight. Among "sales market" indicators, the weight of the question item "wedding apparel store sales/rental" is the highest at .232, accounting for .038 of the total hierarchical weight (Table 5). 
TABLE 5: Indicator weight.

\begin{tabular}{|c|c|c|c|c|}
\hline Items & Indicator weight & $\begin{array}{l}\text { Weights within } \\
\text { the hierarchy }\end{array}$ & Total weights & Sort \\
\hline Product service & $0.320(1)$ & & & \\
\hline Suggestions of different combinations of wedding dress & & 0.205 & 0.057 & 2 \\
\hline Wedding apparel packaged service & & 0.222 & 0.062 & 1 \\
\hline Added services of wedding dress products & & 0.244 & 0.046 & 6 \\
\hline Package/lease contract of wedding dress & & 0.253 & 0.048 & 5 \\
\hline Consultation of wedding dress patterns & & 0.273 & 0.051 & 4 \\
\hline Customized wedding dress & & 0.230 & 0.043 & 7 \\
\hline Product delivery service of wedding dress & & 0.127 & 0.013 & 32 \\
\hline Information platform & $0.290(2)$ & & & \\
\hline Description of lease items of wedding dress lease & & 0.117 & 0.033 & 11 \\
\hline Description of lease terms (time and period) of dress & & 0.284 & 0.029 & 15 \\
\hline Wedding apparel style and opinion platform & & 0.554 & 0.053 & 3 \\
\hline Description of webpage service items of wedding dress & & 0.228 & 0.022 & 23 \\
\hline $\begin{array}{l}\text { Cooperation between wedding dress lease channels and } \\
\text { related wedding enterprises }\end{array}$ & & 0.131 & 0.037 & 10 \\
\hline Delivery package service of wedding dress & & 0.189 & 0.032 & 13 \\
\hline Acquisition of the latest wedding dress information & & 0.123 & 0.021 & 25 \\
\hline Sales/lease of wedding dress channels & & 0.196 & 0.032 & 12 \\
\hline Description of rentals of wedding dress & & 0.193 & 0.031 & 14 \\
\hline Maintenance and recycling & $0.150(4)$ & & & \\
\hline Reduction of cost and creative old wedding dress & & 0.092 & 0.025 & 21 \\
\hline Regular cleaning and maintenance of wedding dress & & 0.101 & 0.026 & 18 \\
\hline Calculation of cleaning expenses of wedding dress & & 0.164 & 0.026 & 19 \\
\hline $\begin{array}{l}\text { Regular elimination of wedding dress to maintain high } \\
\text { quality }\end{array}$ & & 0.152 & 0.025 & 20 \\
\hline Wedding dress is sold to performance artists & & 0.117 & 0.011 & 33 \\
\hline Wedding apparel second-hand auction/donation & & 0.132 & 0.037 & 9 \\
\hline Sales market & $0.240(3)$ & & & \\
\hline Wedding apparel store sales/rental & & 0.232 & 0.038 & 8 \\
\hline Discounts of wedding dress & & 0.143 & 0.023 & 22 \\
\hline $\begin{array}{l}\text { Percentage of lease market of self-service wedding dress } \\
\text { companies is higher }\end{array}$ & & 0.167 & 0.027 & 17 \\
\hline Percentage of wedding dress lease model is higher & & 0.278 & 0.027 & 16 \\
\hline $\begin{array}{l}\text { Bridal photography and self-service wedding dress have } \\
\text { different sales models }\end{array}$ & & 0.218 & 0.021 & 24 \\
\hline $\begin{array}{l}\text { Irregular invitation of wedding dress advertising } \\
\text { endorsers }\end{array}$ & & 0.131 & 0.013 & 31 \\
\hline Newly wed customers' needs for lease market are higher & & 0.119 & 0.020 & 26 \\
\hline Common customers' needs for lease market are higher & & 0.114 & 0.019 & 27 \\
\hline Irregular sending of advertising of wedding dress & & 0.180 & 0.018 & 28 \\
\hline Discounts for new and old customers & & 0.106 & 0.018 & 29 \\
\hline Percentage of buyout model of wedding dress is higher & & 0.101 & 0.016 & 30 \\
\hline
\end{tabular}

Source: compiled by this study.

4.5. Fuzzy Hierarchical Weight Analysis of the Indicators. After the preliminary weight analysis of the system indicators, this study applied the concepts of FAHP proposed by Buckley in computation [13]. It summarized the expert and scholar opinions and scored the fuzzy evaluation values according to the fuzzy semantic definitions. Then, the pairwise comparison matrix table was established and computed using the fuzzy function to obtain the system indicators and the fuzzy weight values of the questionnaire items. The operational process of FAHP is illustrated as follows. 
TABLE 6: List of evaluation scale.

\begin{tabular}{|c|c|c|}
\hline Evaluation scale & Degree of importance & Comparison on importance weights \\
\hline 1 & Equally important & Two factors in pairwise comparison are equally important. \\
\hline 3 & Slightly important & $\begin{array}{l}\text { According to the experience, the first factor in pairwise comparison is slightly } \\
\text { important. }\end{array}$ \\
\hline 5 & More important & $\begin{array}{l}\text { According to the experience, the first factor in pairwise comparison is more } \\
\text { important. }\end{array}$ \\
\hline 7 & Very important & $\begin{array}{l}\text { The case or evidence indicates the first factor in pairwise comparison is very } \\
\text { important. }\end{array}$ \\
\hline 9 & Absolutely important & $\begin{array}{l}\text { The adequate evidence indicates the first factor in pairwise comparison is absolutely } \\
\text { important. }\end{array}$ \\
\hline $2,4,6,8$ & Median between two adjacent scales & Intermediate value is needed. \\
\hline
\end{tabular}

Source: compiled by this study.

\begin{tabular}{|c|c|c|c|c|c|c|c|c|c|c|}
\hline Indicator & \multicolumn{9}{|c|}{ Implications for relative importance degree } & \multirow{2}{*}{\begin{tabular}{|c} 
Indicator \\
Scale
\end{tabular}} \\
\hline Scale & $9: 1$ & $7: 1$ & $5: 1$ & $3: 1$ & $1: 1$ & $1: 3$ & $1: 5$ & $1: 7$ & $1: 9$ & \\
\hline Semantics & $\begin{array}{l}\text { Absolutely } \\
\text { important }\end{array}$ & $\begin{array}{c}\text { Very } \\
\text { important }\end{array}$ & $\begin{array}{c}\text { More } \\
\text { important }\end{array}$ & $\begin{array}{l}\text { Slightly } \\
\text { important }\end{array}$ & $\begin{array}{c}\text { Equally } \\
\text { important }\end{array}$ & $\begin{array}{l}\text { Slightly } \\
\text { important }\end{array}$ & More & $\begin{array}{c}\text { Very } \\
\text { important }\end{array}$ & $\begin{array}{l}\text { Absolutely } \\
\text { important }\end{array}$ & Semantics \\
\hline $\begin{array}{l}\text { Check } \\
\text { column }\end{array}$ & & & & & & & & & & $\begin{array}{l}\text { Check } \\
\text { column }\end{array}$ \\
\hline
\end{tabular}

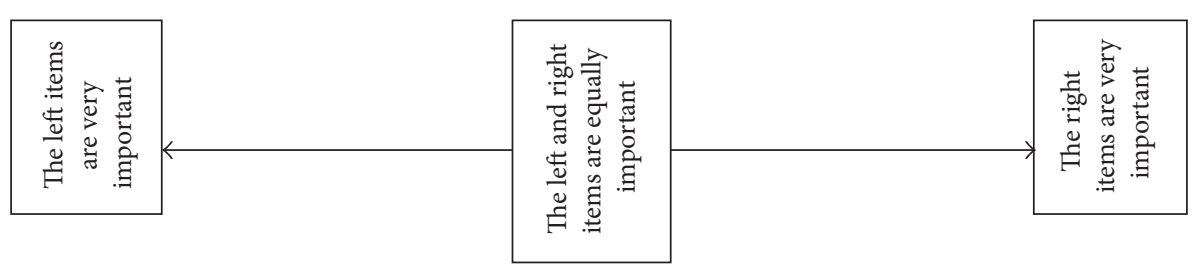

FIGURE 3: List for relative importance.

\subsubsection{Fuzzy Hierarchical Weight Analysis Process}

(1) Establish the Hierarchical Structure. In the hierarchical structure, the influence factors were analyzed through hierarchical analysis. After collection and analysis of the literature and after experts and scholars reached consensus on all question items in two-stage expert Delphi questionnaire survey, the important factors suitable for goal questions were selected. Next, the hierarchical structure was established.

(2) Establish the Fuzzy Pairwise Comparison Matrix. Fuzzy pairwise comparison matrix was established based on relative importance of key factors and the matrix can measure the evaluation value of the criterion items through fuzzy semantic variables. As for the wedding photography apparel product system indicators, according to opinions of experts and scholars this study used FAHP (fuzzy analytic hierarchy process) to analyze weights and obtain the statistical results. Nominal scale was used for FAHP questionnaires. The pairwise comparison between indicator factors within the same layer was conducted to evaluate relative importance of factors. The main evaluation scale is divided into 5 items: equally important, slightly important, more important, very important, and absolutely important, and measured values 1 , $3,5,7$, and 9 were assigned. The left scale means the left factors are more important than the right factors, and the right scale means the right factors are more important than left factors. Significance of each scale is shown in Table 6.

In addition, the relative importance is transformed from the scales to semantics, as shown in Figure 3.

(3) Construct the Positive Reciprocal Value Matrix. The traditional judgment matrix $A=\left[a_{i j}\right]$ is a positive reciprocal value matrix, representing expert views on fuzziness of importance of factors in pairwise comparison after introduction of fuzzy number concept. The triangular fuzzy number $\widetilde{A}=\left[\tilde{a}_{i j}\right]$ is used to integrate views of experts. Hence, fuzzy positive reciprocal value matrix $A$ can be established. Thus, if the pairwise comparison matrix is $\widetilde{A}=n \times n$, evaluation value 
TABLE 7: Analysis of number 1 layer fuzzy weight value.

\begin{tabular}{lcccc}
\hline Items & Fuzzy weight values & Defuzzification weight values & Normalized weight value & Weight value sort \\
\hline Management-oriented & $(1.960,2.174,2.623)$ & 2.252 & 0.614 & 1 \\
Design-oriented & $(0.853,1.076,1.286)$ & 1.072 & 0.333 & 2 \\
Use-oriented & $(0.773,0.895,1.083)$ & 0.917 & 0.250 & 3 \\
Consumption-oriented & $(0.408,0.514,0.570)$ & 0.497 & 0.136 & 4 \\
\hline
\end{tabular}

Source: compiled by this study.

TABLE 8: Analysis of number 2 layer fuzzy weight value.

\begin{tabular}{|c|c|c|c|c|c|c|}
\hline Items & Fuzzy weight values & $\begin{array}{c}\text { Defuzzification } \\
\text { weight values }\end{array}$ & $\begin{array}{l}\text { Normalized } \\
\text { weight value }\end{array}$ & $\begin{array}{c}\text { Weight value } \\
\text { sort }\end{array}$ & $\begin{array}{c}\text { Tandem weight } \\
\text { value }\end{array}$ & $\begin{array}{c}\text { Tandem weight } \\
\text { value sort }\end{array}$ \\
\hline Product service & $(1.159,1.395,1.831)$ & 1.461 & 0.047 & 1 & 0.047 & 1 \\
\hline Information platform & $(0.914,0.974,1.433)$ & 1.107 & 0.036 & 2 & 0.036 & 2 \\
\hline Maintenance and recycling & $(0.706,0.933,1.130)$ & 0.923 & 0.030 & 3 & 0.023 & 4 \\
\hline Sales market & $(0.531,0.789,0.849)$ & 0.723 & 0.023 & 4 & 0.030 & 3 \\
\hline
\end{tabular}

Source: compiled by this study.

of $n(n-1) / 2$ should be calculated because $\widetilde{A}$ is positive reciprocal value matrix:

$$
\operatorname{Matrix} \widetilde{A}=\left[\begin{array}{cccc}
1 & \tilde{a}_{12} & \tilde{a}_{13} & \tilde{a}_{14} \\
\tilde{a}_{21} & 1 & \tilde{a}_{22} & \tilde{a}_{23} \\
\tilde{a}_{31} & \tilde{a}_{32} & 1 & \tilde{a}_{33} \\
\tilde{a}_{41} & \tilde{a}_{42} & \tilde{a}_{43} & 1
\end{array}\right] \text {, }
$$

where $\widetilde{a}_{i j}=1 / \widetilde{a}_{i j}$.

(4) Group Integration. After establishment of fuzzy positive reciprocal value matrix, geometric method is used to integrate views of experts, and the equation is as follows:

$$
\tilde{a}_{i j}=\left(\tilde{a}_{i j}^{1} \times \tilde{a}_{i j}^{2} \times \tilde{a}_{i j}^{3} \times \cdots \times \tilde{a}_{i j}^{N}\right)^{1 / n},
$$

where $\tilde{a}_{i j}: i$ column of reciprocal value matrix and triangular fuzzy number $N$ on the $j$ row.

$\tilde{a}_{i j}^{N}$ : the pairwise comparison value of the $j$ factor for $i$ evaluation indicator.

(5) Fuzzy Weight Calculation. The fuzzy weights were calculated by using column vector geometric method. This method can be used to obtain fuzzy weight of positive reciprocal value matrix, and this can achieve normalization.

(6) Defuzzification. To obtain precise value of each evaluation indicator, defuzzification must be performed in weight calculation. This study applied inverse triangular fuzzy number equation, which is objective, without adding preference of decision makers.

(7) Normalization. In order to compare importance of different dimensions and evaluation indicators, fuzzy weights are normalized.

(8) Hierarchical Serial Connection and Sorting. The hierarchical serial connection can be made when evaluation factors of each layer are consistent and after weight $W i$ of each factor is calculated. The weight of factor $i$ of next layer is multiplied by the weight of the factor of the last layer, and till the first layer, the obtained value or percentage is overall weight of factor $i$. Namely, final fuzzy evaluation $(R i)$ is obtained by multiplying fuzzy evaluation value $(E i)$ by $W i$ fuzzy weight $\left(W i^{\sim}\right)$, and the equation is $R i^{\sim}=E i^{\sim} \times W i^{\sim}$. After sorting the overall weights, the factor layer can be obtained.

4.5.2. Analysis of the Indicator Relative Weight Value. This study used the interview responses of experts to construct the system indicator structure. According to the interview data provided by experts and scholars, this study applied the fuzzy AHP method to obtain the relative weights of various evaluation indicators. The number 1 layer, number 2 layer, number 3 layer, and number 4 layer fuzzy weight values, defuzzification weight values, normalization weight values, and relative importance of dimensions of the system indicators, as well as hierarchical serial connection weights are examined.

(1) Analysis of Number 1 Layer Fuzzy Weight Values. The evaluation of the indicator fuzzy values of the system indicators can be divided into the "management-oriented," "designoriented," "use-oriented," and "consumption-oriented" parts. After the process of fuzzy weight value defuzzification, the normalization weight value of the "management-oriented" dimension weight value at 0.614 is the highest, followed by the "design-oriented" dimension weight value at 0.333 , the "use-oriented" dimension weight value at 0.250 , and the "consumption-oriented" dimension weight value at 0.136 (Table 7).

(2) Analysis of Number 2 Layer Fuzzy Weight Value. After the serial connection of weight value, the sequence of the system indicators is "product service" with serial connection weight value at 0.047 , "information platform" with serial connection weight value at 0.036 , "maintenance and recycling" with serial 


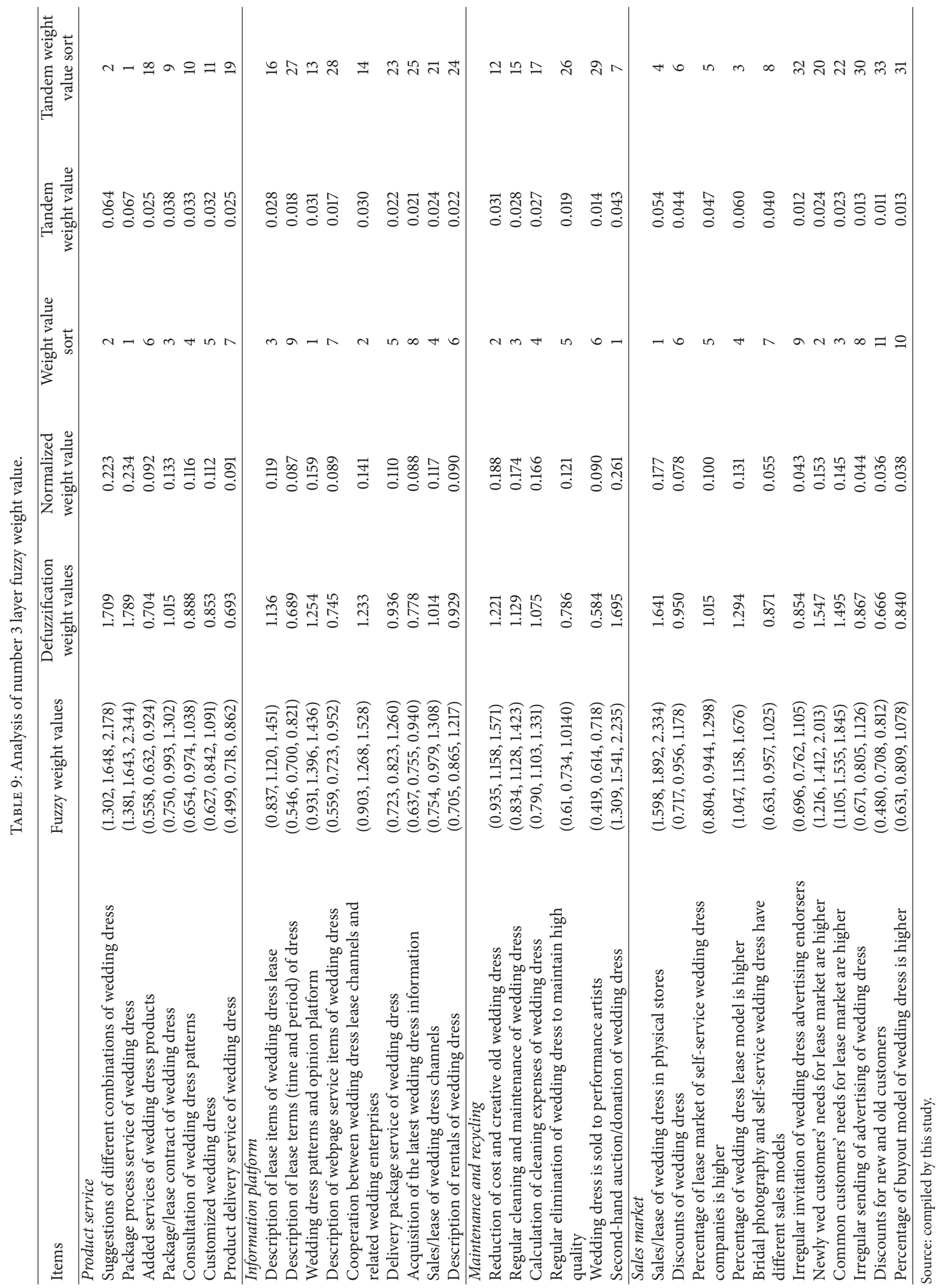


connection weight value at 0.30 , and "sales market" with serial connection weight value at 0.023 (Table 8).

(3) Analysis of Number 3 Layer Fuzzy Weight Value. The analysis of the fuzzy weight values of the product-service indicator is divided into seven question items. After the process of defuzzification weight values, the normalized weight value of "package process service of wedding dress" is the highest at 0.234 . The analysis of the fuzzy weight values of wedding photography apparel product system "information platform" indicator is divided into nine question items. After the process of defuzzification weight values, the normalized weight value of "wedding dress patterns and opinion platform" is the highest at 0.159 . The analysis of the fuzzy weight values of the indicator "maintenance and recycling" indicator is divided into six question items. After the process of defuzzification weight values, the normalized weight value of "second-hand auction/donation of wedding dress" is the highest at 0.261 . The analysis of the fuzzy weight values of the "sales market" indicator is divided into eleven question items. After the process of defuzzification weight values, the normalized weight value of "sales/lease of wedding dress in physical stores" is the highest at 0.177 (Table 9).

\section{Conclusions}

Based on the analysis and discussion of the results, this study proposed the conclusions and explanations. According to the analysis results of the fuzzy weights of the wedding photography apparel product system indicators, the most important indicators are product-service indicators followed by information platform indicators, the maintenance and recycling indicators, and the sales market indicators. Moreover, among the product-service indicators, the most important indicator is the wedding apparel package service. Among the information platform indicators is the wedding apparel style and opinion platform. Among the maintenance and recycling indicators, the wedding apparel second-hand auction/donation is the most important indicator. Among the sales market indicators, the wedding apparel store sales/rental is the most important. The following is the conclusion of this study.

(1) The Expert Delphi Results System Indicators. The results of the two-stage expert Delphi questionnaire survey results suggested that they reached a high degree of consensus on 33 question items of four indicators in four dimensions. The indicators and question items of this study can fully represent the key points of the planning of the wedding photography apparel product system. Factors such as the diversified planning of the wedding photography apparel product functions, the service convenience in consumer selection, and the compliance with reuse requirements in apparel design should be considered. The feasibility evaluation and analysis of the wedding apparel industry in the southern area were conducted to learn about the environmental conditions and the regional culture, which is meaningful to the wedding photography apparel product system. In addition, more importantly, the review by experts of the planning dimension contents can ensure the task and working content of each stage. Such a strict reviewing can facilitate the quality and effectiveness of the subsequent wedding photography apparel product system. Therefore, the indicators and question items of the dimensional planning of this study can effectively provide a reference in the present and future wedding photography apparel product system for the perfection of the planning and design of the wedding photography companies.

(2) Fuzzy Weight Analysis of Indicators of Various Dimensions. According to the results of the fuzzy weight analysis, the priority of the wedding photography apparel product system is the focus on relevant implications of the product service. The relevant elements mentioned in this study should be included in the wedding photography apparel product service, online platform planning, wedding apparel design, and evaluation. The detailed analysis and consideration at this stage can reduce the subsequent reuse design problems. In addition, the priority of the wedding apparel is fabric quality. In this study, we also proposed relevant elements and methods to control the fabric quality, expecting that consumers can have the feeling of fashion. It is noteworthy that all the facilities of wedding photography companies should be comprehensively managed. Attention should be paid to hardware facilities as well as the maintenance and repair of equipment in advance.

(3) Sorting Results of Serial Connection Weights of Questionnaire Items in Various Dimensions. Regarding the top 10 question items of wedding photography apparel product system by fuzzy weight value sorting, the wedding apparel packaged service has the highest weight value after the serial connection, followed by the suggestions of wedding apparel matching programs, wedding apparel style and opinion platform, wedding apparel style service consultancy, wedding apparel package/rental contract, wedding apparel additional service, wedding apparel customization, wedding apparel store sales/rental, wedding apparel second-hand auction/donation, wedding apparel rental channel, and related wedding service companies. In summary, the conditions for the use of the wedding photography apparel product system, consumer demand and information network convenience, the photography equipment maintenance, and related wedding service cooperation companies, or the explanations of the use of information network, should be considered in planning.

\section{Conflict of Interests}

The authors declare that there is no conflict of interests regarding the publication of this paper.

\section{References}

[1] Y. Y. Lee, "Make your dream to be a star come true: analysis on consumption culture of wedding dress photography wind turbine aerodynamic performance and novel floating system in Taiwan," Taiwan: A Radical Quarterly, vol. 36, pp. 147-185, 1999.

[2] Y. P. Chen and H. L. Hu, "Study on product-service systems and current implementation in Taiwan industries: using chemical 
manufacturing industry as an example," Paper Collection of Conference of Cleaning, Production and Sustainable Development, Industrial Development Bureau, Ministry of Economic Affairs, 2003.

[3] O. K. Mont, "Clarifying the concept of product-service system," Journal of Cleaner Production, vol. 10, no. 3, pp. 237-245, 2002.

[4] H. Brezet, "Product-service substitution: examples and cases fron the Netherlands, functions for saljning-product-service systems, Stickholm," AFR-Report 299, Swedish Environmental Protection Agency, 2002.

[5] F. H. Beuren, M. G. Gomes Ferreira, and P. A. Cauchick Miguel, "Product-service systems: a literature review on integrated products and services," Journal of Cleaner Production, vol. 47, pp. 222-231, 2013.

[6] G. T. Kuo, "Exploratory study on sustainability of product servitization," in Proceedings of the Conference of Ecological Society and International Sustainable Development, pp. 113-128, 2010, Paper Collection.

[7] A. Tukker, "Eight types of product-service system: eight ways to sustainability? Experiences from suspronet," Business Strategy and the Environment, vol. 13, no. 4, pp. 246-260, 2004.

[8] H. A. Linstone and M. Turoff, The Delphi Method: Techniques and Applications, Addison-Wesley, Reading, Mass, USA, 2002.

[9] Y. C. Ku, Enterprise Research Method, Hua Tai, Taipei City, Taiwan, 1996.

[10] A. L. Delbecq, d. V. Van, and A. H. Gustafason, Group Techniques for Program Planning: A Guide to Nominal Group and Delphi Processes, Scott, Foresman and Company, Glenview, Ill, USA, 1975.

[11] C. Duffield, “The Delphi technique," The Australian Journal of Advanced Nursing, vol. 12, pp. 41-45, 1988.

[12] D. A. Jenkins and T. E. Smith, "Applying Delphi methodology in family therapy research," Contemporary Family Therapy, vol. 16, no. 5, pp. 411-430, 1994.

[13] J. J. Buckley, "Fuzzy hierarchical analysis," Fuzzy Sets and Systems, vol. 17, no. 3, pp. 233-247, 1985.

[14] T. L. Saaty, "How to make a decision: the analytic hierarchy process," European Journal of Operational Research, vol. 40, pp. 9-10, 1971. 


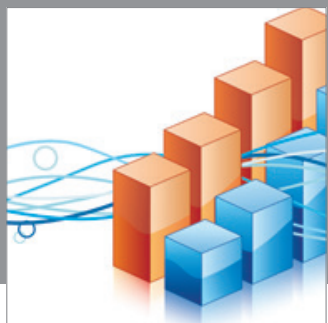

Advances in

Operations Research

mansans

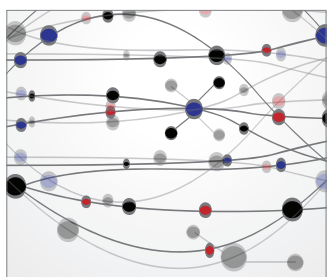

The Scientific World Journal
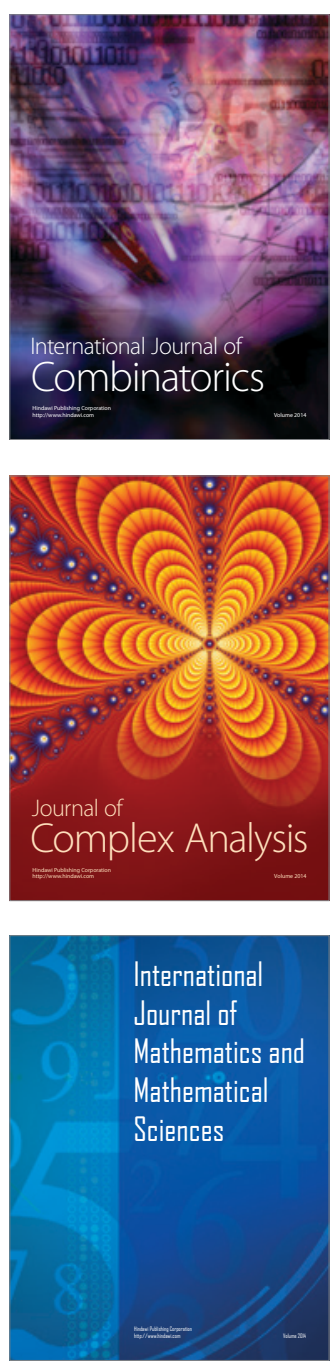
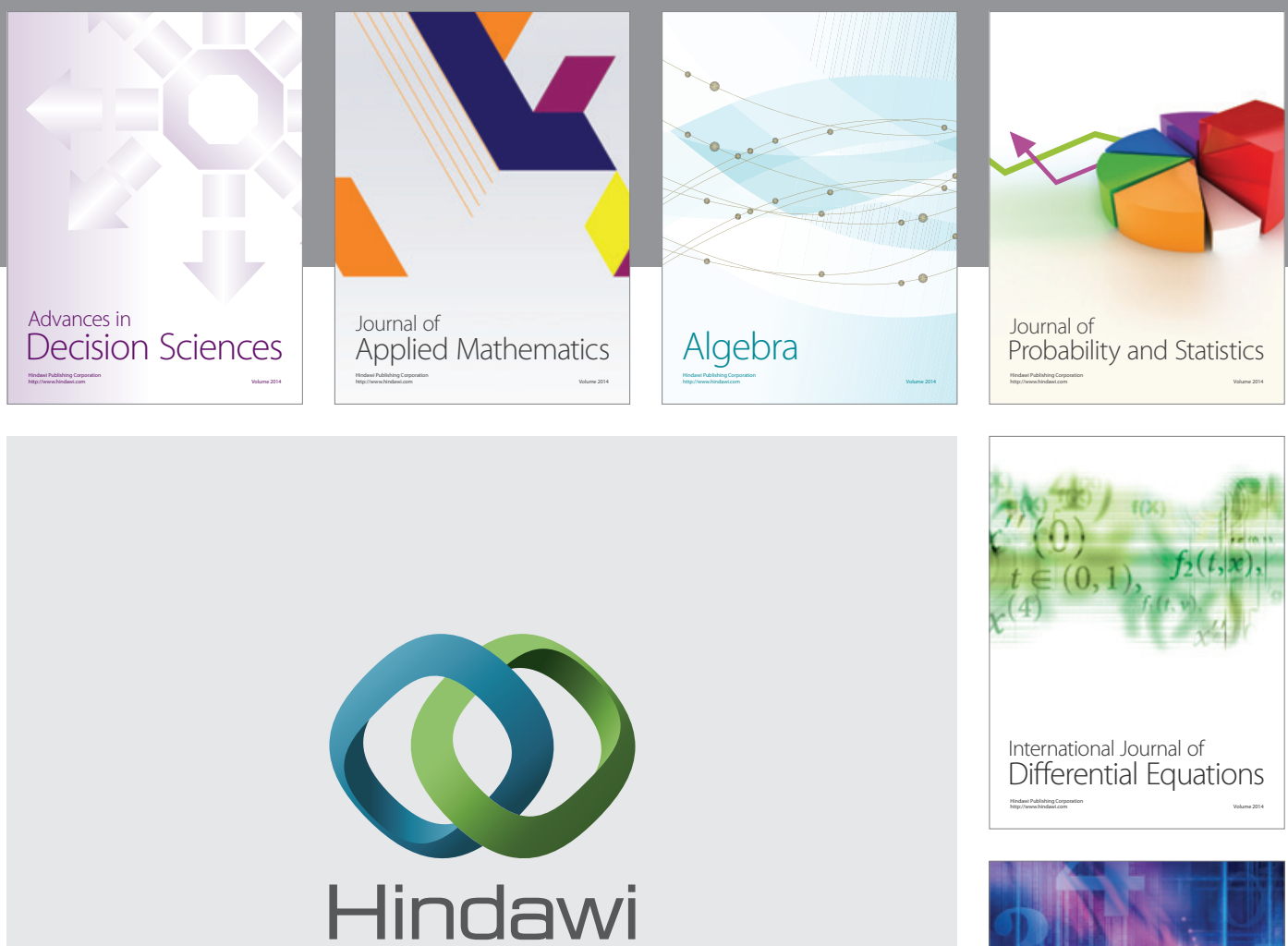

Submit your manuscripts at http://www.hindawi.com
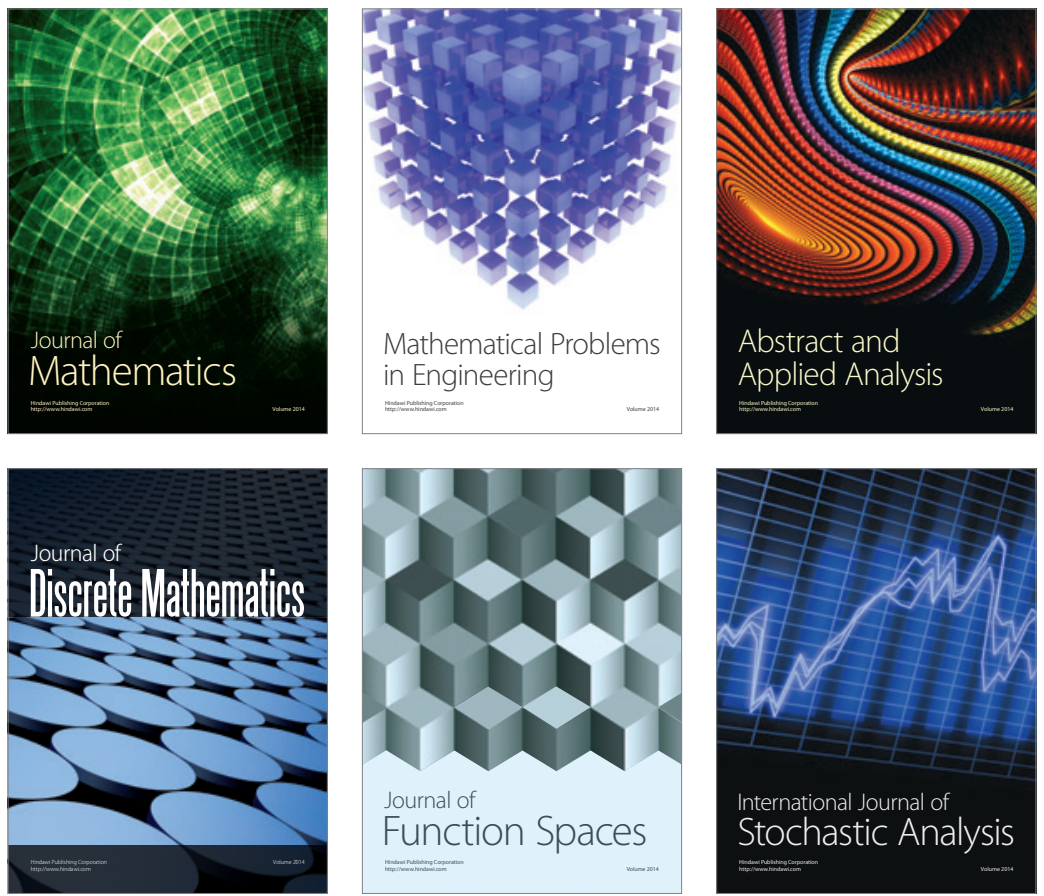

Journal of

Function Spaces

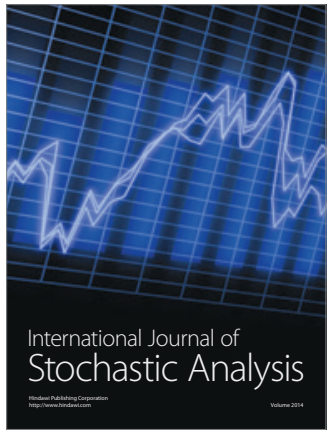

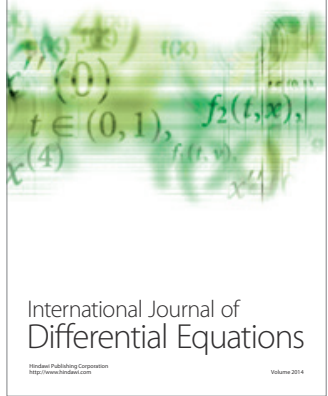
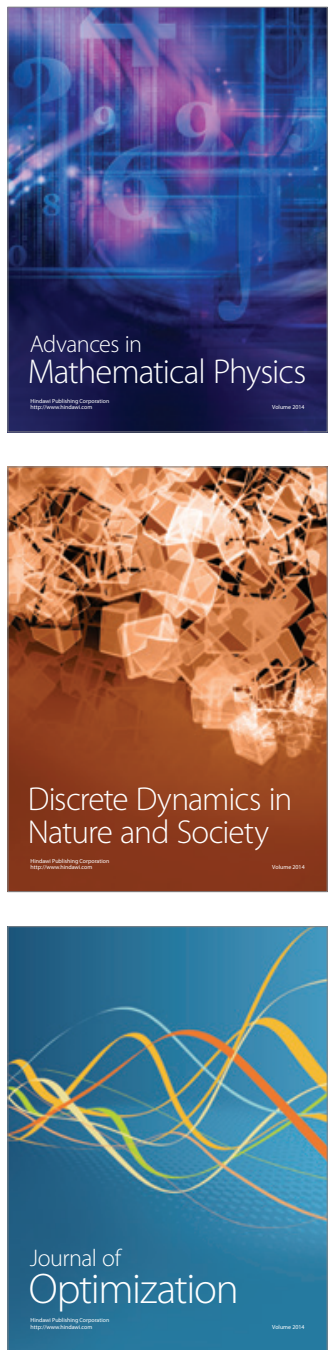